\title{
Personality correlates of prejudice against AIDS victims
}

\author{
JEAN CUNNINGHAM, STEPHEN J. DOLLINGER, MADELYN SATZ, and NANCY ROTTER \\ Southern Illinois University, Carbondale, Illinois
}

For a variety of reasons, the classic personality psychology construct of the authoritarian personality ought likely to be linked with prejudicial attitudes toward persons with acquired immune deficiency syndrome (AIDS). In this study of 177 college students, we tested that relation, while at the same time we included a number of likely correlates of authoritarianism: toughmindedness (e.g., low $n$ nurturance, high $n$ aggression), low intelligence, absolutist ethical thinking, self-righteousness, sexual conservatism, and religiosity. Nearly all of the predictors accounted for small portions of variance in prejudice. The five best predictors of prejudice-authoritarianism, low nurturance, ethical absolutism, low intelligence, and male gender-yielded a multiple $R$ of .57 .

Although public attitudes toward people with AIDS have been termed an "epidemic of stigma" (Herek \& Glunt, 1988), little is known about the personal characteristics associated with prejudice toward or compassion for such victims. Recently, however, studies have begun to suggest relations between AIDS attitudes and knowledge about AIDS (Royse, Dhooper, \& Hatch, 1987), religious fundamentalism (Johnson, 1987), attitudes toward homosexuality (O'Donnell et al., 1987; Triplet \& Sugarman, 1987), and dogmatism and authoritarianism (Larsen, Elder, Bader, \& Dougard, 1989; Witt, 1989a, 1989b).

Classic research in the area of personality and social psychology suggests that an important predictor of prejudice is the degree to which a person possesses the constellation of traits described in The Authoritarian Personality (Adorno, Frenkel-Brunswik, Levinson, \& Sanford, 1950). Particularly relevant within this constellation are "a tendency to reject and punish people who violate conventional values" and "exaggerated concerns with sexual 'goings-on' ', (Adorno et al., 1950, pp. 225-227). These qualities should enable the authoritarian to take special pleasure in hating AIDS victims, because AIDS is generally seen as a disease of homosexuals and drug users.

In their American student sample $(N=101)$, Larsen et al. (1989) found a small but significant $r$ of .17 between the F scale (Adorno et al., 1950) and their 20-item measure of AIDS attitudes. This finding did not hold true for international students (Japanese and other Asian students) in their sample. Witt (1989a), who used the F scale and a 16-item "affect toward persons with AIDS" scale, reported a significant correlation of $.31(N=416)$. In a subsequent study, Witt (1989b) used Ray's (1972) balanced F scale and found a correlation of $.45(N=136)$. He also found that measures of locus of control and belief in a just

Address correspondence to Stephen J. Dollinger, Department of Psychology, Southern Illinois University, Carbondale, IL 62901. world were unrelated to the AIDS attitude measure. The study to be described here, which was conducted in 1986, adds to this growing literature. In it, we looked at authoritarianism in connection with a number of likely correlates of the construct (cf. Dillehay, 1978), including the valuing of toughness/rejection of tenderness, low intelligence, self-righteous or dogmatic thinking, religiosity, and attitudes about sexuality.

\section{METHOD}

\section{Subjects}

Seventy-two male and 105 female college students took part in large group sessions, providing their responses to a variety of surveys in a 150 -min session. The subjects were encouraged to take a break and have a soft drink (provided by the experimenter) between survey forms to minimize fatigue and encourage cooperation. The data from an additional 20 subjects who participated were excluded for endorsing more than 1 of 4 items designed to screen for random responding or acknowledged difficulty in understanding items in the surveys.

\section{Attitudes Toward AIDS Measure}

The criterion variable for this report was based on five items pertaining to AIDS, three of which were stated with a negative (prejudicial) tone and two with a more positive tone. The subjects indicated their thinking on each, using a scale from 1 (strongly disagree) to 5 (strongly agree). The items were as follows.

1. AIDS is a punishment from God.

2. AIDS is a medical problem that eventually could spread to the general population; we all need to be concerned about it. (reversed)

3. I would feel embarrassed and ashamed if someone close to me had AIDS.

4. Charities for AIDS research are as worthy of my donations as other medically related charities. (reversed)

5. Most people who contract AIDS are getting what they deserve.

With the exception of Item 2, these items intercorrelated in the appropriate directions $|r|=.24$ to .54 , median $r=.42, p<.001$. Item 2 did not correlate significantly with the others. The AIDS attitude composite, excluding Item 2, had an alpha coefficient of .71 . It was scored so that higher values reflected more prejudiced, derogatory attitudes. Although a brief scale, it included ideas similar to those in the main factors identified in recently published studies by Lester (1989) and Heaven, Connors, and Kellehear (1990). Mean sex differences on this measure $[t(159)=4.02, p<.001]$ indicated that, although neither group was highly prejudiced against AIDS victims, women had less deroga- 
tory attitudes than did men $(M s=7.3$ vs. 9.4$)$. This sex difference is consistent with the findings of Lester (1989) and Heaven et al. (1990).

\section{Predictors}

The predictor variables and their associated measures included the following.

Authoritarianism. Byrne and Kelley's (1981) 22-item authoritarianism scale was used $(\alpha=.73)$. This scale was designed to correct for the fact that, in the original F scale (Adorno et al., 1950), acquiescence and authoritarianism were confounded. Byrne's version of the scale has been used successfully to predict, for example, political preferences (Byrne \& Przybyla, 1980), sentencing recommendations in simulated trials (Rykman, Burns, \& Robbins, 1986), and differential recall of prosecution versus defense evidence from the Patty Hearst trial (Garcia \& Griffitt, 1978). Sample items include the following: "A person who has bad manners, habits, and breeding can hardly expect to get along with decent people," and "Obedience and respect for authority are the most important virtues children should learn." None of the items refers to sexuality in any form.

To provide additional internal validation for the scale in the present sample, we related authoritarianism to endorsement of 10 of Wilson and Patterson's (1968) topics in their conservatism scale (which follows a simple "yes, no, uncertain" format). Authoritarianism was related to 7 of these items: evolution theory, disarmament, and mixed marriage, with endorsers of these concepts scoring as less authoritarian than nonendorsers $(p<.01)$; and apartheid, censorship, strict rules, and Bible truth, with endorsers scoring as more authoritarian $(p<.01$, except in the case of apartheid, with $p<.05$ ). Authoritarianism failed to be related to endorsement of the concepts of patriotism, working mothers, or socialism.

Sexual liberalism/conservatism. Snyder, Simpson, and Gangestad (1986) devised a reliable ( $\alpha=.80)$ two-item measure termed sex-withoutcommitment. The items included the following: "For me, having sex with someone does not necessarily imply that I am committed to that individual," and "I would not have sex with someone unless I was totally and exclusively committed to that person." Snyder et al. showed that this scale was meaningfully related to a variety of other self-reported sexual attitudes and behaviors.

Self-righteousness. Falbo and Shepperd (1986) attempted to improve on the dogmatism construct by separating the cognitive and affective components of it. Their four-item self-righteousness scale $(\alpha=.73$ in their research, .65 in the present study) measures the cognitive component, also known as closed-mindedness. An exemplary item is the statement "People who disagree with me are wrong." Falbo and Shepperd showed meaningful relations between self-righteousness (when combined with self-esteem) and perspective taking, power strategies, and religious motivation.

Toughness/tenderness. Murray's (1938) needs for nurturance, affiliation, dominance, and aggression seem to provide good operationalizations of the pro-toughness, rejection-of-tenderness component thought to be associated with authoritarianism. We therefore selected four of Jackson's (1974) Personality Research Form (PRF) scales as measures of tenderness or communal qualities (needs for nurturance and affiliation) and toughness (dominance and aggression). According to the PRF manual, these scales had test-retest reliabilities ranging from .79 to .88 , KR-20 reliabilities ranging from .73 to .86 , and validity coefficients (using behavior ratings by others) ranging from .27 to .69 , with the median equalling .42. In the present study, coefficient alphas were .64 for nurturance and aggression, .76 for affiliation, and .78 for dominance.

Intelligence. To provide a measure of intelligence, we created a 35item simulated Miller Analogies Test with items drawn from Sternberg's (1981) How to Prepare for the MAT. This measure had a coefficient alpha of .62. In unpublished research by Dollinger (1988), it has been found to be significantly related to scores on the WAIS Similarities test, the Nelson-Denny Reading Comprehension test, and the ACT college entrance test scores and to discriminate between students who grant and refuse to release their ACT scores for research (all $p s<.01$ ).

Religiosity. Finally, three items used by the second author in related research were given as measures of religious behavior, cognition, and affect. These were 5-point ratings of frequency of attendance at religious services, frequency of thinking or talking about religious and philosophical questions, and frequency of experiencing religious feelings such as "closeness to God." All are similar to Allport's concept of intrinsic religiosity (Allport \& Ross, 1967), and in past unpublished research, a composite of the three correlated .70 with a measure of intrinsic religiosity.

Ethical ideologies. For brevity and meaningfulness, we selected pairs of items from Forsyth's (1980) ethical ideologies scales for idealism and relativism. We selected items that were more "answerable" by the typical undergraduate without considerable thought or clarification. For idealism, we used the following statements: "One should never psychologically or physically harm another person," and "If an action could harm an innocent person, then it should not be done." For relativism, we used these statements: "What is ethical varies from one situation and society to another," and "Questions of what is ethical for everyone can never be resolved; what is moral or immoral is up to the individual." Given the modest levels of reliability of these abbreviated scales (for both, $\alpha=.51$ ), some caution is warranted in any attempt to interpret the measures. However, it was noted that these scales were significantly correlated $(p<.001)$ in meaningful ways with several other measures in the study. Most notably, the more idealistic a subject, the higher was the subject's need for affiliation $(r=.29)$; the lesser the subject's idealism, the higher the need for aggression $(-.29)$ and the higher the self-righteousness (-.34). Those who rejected relativism were more authoritarian $(-.32)$, self-righteous $(-.24)$, and sexually conservative $(.20, p<.01)$. These results are consistent with findings on the full-length version of the scales (Forsyth, Nye, \& Kelley, 1989; Singh \& Forsyth, 1989).

\section{RESULTS AND DISCUSSION}

With a stringent $p$ level of .001 , the AIDS composite correlated with seven of the predictors: self-righteousness $(r=.37)$, ethical relativism $(r=-.37)$, authoritarianism $(r=.34)$, nurturance $(r=-.34)$, gender (coded 0 $=$ male, $1=$ female; $r=-.29)$, affiliation $(r=-.29)$, and analogies $(r=-.25)$.

To understand these relations better, a simultaneous regression analysis predicted the AIDS composite from these seven predictors. This regression model was significant $[F(7,167)=13.0, p<.001$, multiple $R=.59]$, accounting for $35 \%$ of the variation in AIDS prejudice. Significant predictors in this regression included authoritarianism $(\beta=.21, p<.01)$, low ethical relativism $(-.19, p<.01)$, low nurturance $(-.18, p<.05)$, male gender $(-.17, p<.05)$, and low scores on analogies $(-.14, p<.05)$. When the nonsignificant effects for self-righteousness and affiliation are trimmed from the model, the resulting regression equation still accounts for $33 \%$ of the variance (multiple $R=.57$ ), and the beta for nurturance rises notably $(-.27, p<.001)$.

Thus, we can characterize the person who derogates AIDS victims as an emotionally nonnurturant, authoritarian male who is of limited intelligence and who is an absolutist in his thinking about right and wrong. He also tends to be self-righteous in his belief systems. In general, these results are consistent with expectations based on the psychology of prejudice, and they support the idea that authoritarianism and a constellation of related traits are predictive of prejudice against AIDS victims. The results are also consistent with but extend other recent studies on such prejudice (Larsen et al., 1989; Witts, 1989a, $1989 b$ ). From these results, it would seem that the individual most likely to be prejudiced against the AIDS 
victim is the person least likely to be influenced by educational efforts (cf. Bouton et al., 1989; Herek \& Glunt, 1988). Thus, a worthy question for future research is whether the unintelligent, self-righteous authoritarian possesses erroneous information about AIDS.

\section{REFERENCES}

Adorno, T. W., Frenkel-Brunswik, E., Levinson, D., \& SanFORD, N. (1950). The authoritarian personality. New York: Harper.

Allport, G. W., \& Ross, J. M. (1967). Personal religious orientation and prejudice. Journal of Personality \& Social Psychology, 5, $432-443$.

Bouton, R. A., Gallaher, P. E., Garlinghouse, P. A., Leal, T., Rosenstein, L. D., \& Young, R. K. (1989). Demographic variables associated with fears of AIDS and homophobia. Journal of Applied Social Psychology, 19, 885-901.

ByRNe, D., \& KeLley, K. (1981). An introduction to personality. Englewood Cliffs, NJ: Prentice-Hall.

Byrne, D. , \& Przybyla, D. P. J. (1980). Authoritarianism and political preferences in 1980. Bulletin of the Psychonomic Society, 16, 471-472.

Dillehay, R. C. (1978). Authoritarianism. In H. London \& J. E. Exner, Jr. (Eds.), Dimensions of personality (pp. 85-127). New York: Wiley.

Dollinger, S. J. (1988). [Brief intellectual measures for research with college students.] Unpublished raw data.

Falbo, T., \& Shepperd, J. A. (1986). Self-righteousness: Cognitive, power, and religious characteristics. Journal of Research in Personality, 20, 145-157.

FORSYTH, D. R. (1980). A taxonomy of ethical ideologies. Journal of Personality \& Social Psychology, 39, 175-184.

FORSYTH, D. R., NYE, J. L., \& Kelley, K. (1989). Idealism, relativism, and the ethic of caring. Journal of Psychology, 122, 243-248.

GARCIA, L., \& GRIFFITT, W. (1978). Evaluation and recall of evidence: Authoritarianism and the Patty Hearst case. Journal of Research in Personality, 12, 57-67.

Heaven, P. C. L., Connors, J., \& Kellehear, A. (1990). Structure and demographic correlates of attitudes toward AIDS sufferers. Journal of Psychology, 124, 245-252.

Herex, G. M., \& Glunt, E. K. (1988). An epidemic of stigma: Public reaction to AIDS. American Psychologist, 43, 886-891.

JACKson, D. N. (1974). Personality Research Form manual. Port Huron, MI: Research Psychologists Press.
Johnson, S. D. (1987). Factors related to intolerance of AIDS victims. Journal for the Scientific Study of Religion, 26, 105-110.

Larsen, K. S., Elder, R., Bader, M., \& Dougard, C. (1989). Authoritarianism and attitudes toward AIDS victims. Journal of Social Psychology, 130, 77-80.

LeSTER, D. (1989). Attitudes toward AIDS. Personality \& Individual Differences, 10, 693-694.

MurRay, H. A. (1938). Explorations in personality. New York: Oxford University Press.

O'Donnell, L., O'Donnell, C. R., Pleck, J. H., Snarey, J., SNAREY, R., \& Richard, M. (1987). Psychosocial responses of hospital workers to acquired immunodeficiency syndrome. Journal of Applied Social Psychology, 17, 269-285.

RAY, J. J. (1972). A new balanced " $F$ " scale and its relation to social class. Australian Psychologist, 7, 155-166.

Royse, D., DhoOper, S. S., \& HATCh, L. R. (1987). Undergraduate and graduate students' attitudes toward AIDS. Psychological Reports, 60, $1185-1186$.

Rykman, R. M., Burns, M. J., \& Robbins, M. A. (1986). Authoritarianism and sentencing strategies for low and high severity crimes. Personality \& Social Psychology Bulletin, 12, 227-235.

SiNGH, B., \& ForsYTH, D. R. (1989). Sexual attitudes and moral values: The importance of idealism and relativism. Bulletin of the Psychonomic Society, 27, 160-162.

Snyder, M., Simpson, J. A., \& Gangestad, S. (1986). Personality and sexual relations. Journal of Personality \& Social Psychology, 51, $181-190$

STERNBERG, R. J. (1981). Barron's how to prepare for the MAT. Woodbury, NY: Barron's.

Triplet, R. G., \& Sugarman, D. B. (1987). Reactions to AIDS victims: Ambiguity breeds contempt. Personality \& Social Psychology Bulletin, 13, 265-274.

Wilson, G. D., \& Patterson, J. R. (1968). A new measure of conservatism. British Journal of Social \& Clinical Psychology, 7, 264-269.

WITT, L. A. (1989a). Authoritarianism, knowledge of AIDS, and affect toward persons with AIDS: Implications for health education. Journal of Applied Social Psychology, 19, 599-607.

WITt, L. A. (1989b). Factors affecting attitudes toward persons with AIDS. Journal of Social Psychology, 130, 127-129.

(Manuscript received October 20, 1990.) 